\title{
A global player in a successful International business arena : A Language perspective
}

\section{KEYWORDS}

Global player, International business, language perspective

\section{Dr. Jyothi Venkatesh}

Asst.Professor in French, Dept. of Foreign Languages, Bangalore University, P.K.Block, Palace Road, Bangalore-560009

ABSTRACT With the ongoing globalization process, Nations are coming closer and business ties among them are on the increase. In such a scenario, a real global player would be one whose foreign language expertise would not only break the language barrier, but could be instrumental in actually sealing a business deal.

"If education is a means to prepare students for a complicated world they inhabit, then the educational system cannot deprive students of a general education in the area of foreign language. The value of such an education not only lies in job preparation but also in developing an understanding of other people and cultures." according to Bernadette Morris, Business Analyst.( www.jstor.org)

The proof of the matter lies in the fact that today learning a foreign language is so very important not only for a successful international business development, but it communicates respect and conveys verbally and non- verbally a positive regard and a sincere interest in people and their culture.

For a sound business relationship, such a platform is of foremost importance. Speaking in a language which forges business alliances at the drop of a 'bonjour', 'danke' or 'arigato', will not only break the 'ice' but will also aide seal business relationships.

Today, due to the ongoing globalization and advances in communication, which is bringing nations closer, foreign assignments are becoming the norm of the day. Knowledge of foreign language will ensure greater chance to a candidate to be selected for foreign assignments, as it will show that the candidate is willing to get involved in someone else's culture.

Many companies globally are making strong efforts to recruit people who are bi-or multilingual. According to the Director of Human Resources at Coca - Cola, when his department searches its data base for people to fill overseas posts, the first choice is often someone who speaks more than one foreign language. It is clearly understood that the employee with additional language abilities will make them more useful to the firm.

As already stated above, the globalization phenomena has broken the barrier of doing business within a select group of nations and today companies go all over the globe to source business. It will not be wrong to say that due to the proliferation of foreign language in the business community, business globally has increased manifold in the last 15 years.

In the European market, a company which wishes to do business in a French or German speaking environment will do very well if they send their executive with French / German language abilities to close deal and open up new business avenues.

Although English is widely used in European business, it is still not seen as a totally international language, especially in France \& Germany. In a survey of leading executives in European Countries, only 31\% reported using English for professional purposes. Increasingly, English alone cannot to be used to penetrate the non-English speaking markets

Japan too proves to be a major example of this pattern. Japanese society invests heavily in English language education. Six years of English are required before high school graduation. Japanese Corporations provide tuition for English - language classes. Yet the difficulty in doing business in Japan is in their insistence that business be dealt with in Japanese only. It's as if the Japanese see their language as a prized capital which ensures much more self - control. Even though it is possible to do business by hiring a translator, one may argue, but people will not trust him or her if they are relying only on a translator for everything

The reason is culture. The awareness of the cultural differences that exists from society to society marks the beginning of new business standards in the global international manager of today. He or she needs this new 'skill set' that is of empathy to appreciate a new culture. This comes only with the knowledge of a foreign language, thereby enabling him or her to:

1. Be able to tolerate ambiguity and cope with cultural differences and the frustration that frequently develops when things are different and circumstances change;

2. Display empathy by understanding the other people's needs and differences from their view point rather than from the individual's own view point;

3. Be non-judgmental, avoid judging the behavior of others on their own value standards;

4. Recognize their own cultural values as an influence on their perceptions, evaluations, and judgment in a situation, and

5. Seek good sense of humor and thus help close business deals in a foreign country.

In order to be to be a player in international business, language skills are of utmost importance. Breaking the language and cultural barriers should be the first goal. If you do not speak foreign languages you might not be aware of certain cultural 'Faux-pas' which could become one of the major impediments in striking the right deal ! The competition will speak more than one language! By this way, he or she will be more competent to meet new challenges of doing business with foreigners, and not you!

A strong sought after Manager of today should have the following attributes:

a) A good work experience locally,

b) A couple of good foreign assignments, which is possible if he or she is fluent in at least two foreign languages (apart from English) - preferably one European and one Asian.

c) Is conversant in a few other languages, thus reflecting his 


\section{RESEARCH PAPER}

or her foreign assignments, and has

d) Management experience in marketing, operations and / or finance.

Such a person is surely destined for a top - level executive position in a global arena. As communication (or more precisely language) is a key factor in developing trust, commitment, cultural affinity, experience, and satisfaction.

\section{Conclusion}

In the coming years, companies choices of leaders will be governed by increasing international competition, further globalization of companies, progress in technology, demographic shifts, and the speed of the overall change. However, one of the main attributes will be that such leaders be international 'players' - for which they must be multicultural and multilingual, apart from being multifunctional. 